Sari Pediatri, Vol. 5, No. 1, Juni 2003: 2 - 3

\title{
Thalassemia dan Permasalahannya Di Indonesia
}

\author{
Iskandar Wahidiyat
}

$\tau$

halassemia merupakan kelainan genetik terbanyak di dunia. Kelainan ini diturunkan secara resesif menurut hukum Mendel. Penyakit yang semula ditemukan di sekitar Laut Tengah ini ternyata tersebar luas sepanjang garis khatulistiwa, termasuk Indonesia. Tidak kurang dari 300.000 bayi dengan kelainan berat penyakit ini dilahirkan setiap tahun di dunia, sedangkan jumlah penderita thalassemia heterosigotnya tidak kurang dari 250 juta orang.

Hingga saat ini belum ditemukan obat yang dapat menyembuhkan penyakit tersebut. Pengobatan utama penyakit ini ialah pemberian transfusi darah dengan mempertahankan kadar hemoglobin di atas $10 \mathrm{~g} / \mathrm{dl}$; tetapi ironisnya ialah bahwa jumlah zat besi yang tertimbun dalam organ-organ tubuhnya akibat transfusi, menjadi salah satu penyebab kematian. Penimbunan zat besi dalam organ-organ tubuh seperti hati, jantung, kelenjar endokrin dan lain-lain, menyebabkan gangguan fungsi organ tersebut. Gangguan fungsi organ mulai tampak pada anakanak yang telah mendapat banyak transfusi darah yaitu anak-anak yang berumur 5 th ke atas.

Transfusi darah ini diberikan seumur hidupnya, umumnya jarak antara dua seri transfusi darah berkisar antara 2-3 bulan. Transfusi yang berulang-ulang inilah sebenarnya yang menimbulkan banyak komplikasi dalam penanganan penderita thalassemia. Kadar besi darah (feritin) akan terus meningkat bila tidak diberikan obat khelasi untuk mengeluarkan besi dari tubuh. Penimbunan besi dalam hati akan mengganggu fungsi hati, demikian pula dalam pankreas akan menimbulkan gejala diabetes. Dalam kelenjar endokrin, penimbunan besi akan mengganggu pertumbuhan atau perkembangan seksualnya.

Bahaya lain dari pemberian transfusi darah yang berulang ialah masuknya infeksi yang ditularkan melalui transfusi darah seperti, hepatitis, HIV, parasit dan lain-lain.

\footnotetext{
Alamat Korespondensi:

Prof.DR.Dr. Iskandar Wahidiyat, Sp.A(K).

Subbagian Hematologi.Bagian Ilmu Kesehatan Anak FKUI, Jakarta Jl. Salemba no. 6, Jakarta 10430.

Telepon: 021-31901170.
}

Besi yang tertimbun dalam badannya sebenarnya dapat dikurangi dengan pemberian obat khelasi besi yang diberikan selama 5 hari dalam 1 minggu melalui pompa suntikan (syringe-pump); namun mahalnya obat tersebut sehingga tidak terjangkau oleh pasien-pasien kita. Obat khelasi besi itu akan diberikan seumur hidupnya, apabila kadar feritin darah telah melebihi $2000-2500 \mathrm{ng} / \mathrm{ml}$ atau mereka yang telah mendapat transfusi darah lebih dari 10 kali. Sebaiknya kadar feritin darah dipertahankan pada kadar kurang dari $2000 \mathrm{ng} / \mathrm{ml}$.

Pompa suntikan yang ada di Unit Thalassemia Bagian Ilmu Kesehatan Anak FKUI/RS. Dr. Ciptomangunkusumo Jakarta sekarang, merupakan sumbangan dari para donatur dalam dan luar negeri. Alat tersebut dipinjamkan kepada pasien-pasien yang memerlukannya. Tidak lebih dari 75 diantara 1000 orang pasien yang memakai khelasi besi (desferal) 3$5 \mathrm{x} /$ minggu di Unit Thalassemia tersebut. Saat ini sedang diusahakan penggunaan pemberian khelasi besi oral (deferiprone) bagi pasien-pasien thalassemia di Bagian IKA. Meskipun masih ada pertentangan mengenai penggunaan khelasi besi oral ini, terutama dari segi efek sampingnya; penggunaan obat tersebut untuk negara berkembang akan sangat menolong penderita, di samping harganya yang jauh lebih murah, penggunaannya juga lebih sederhana.

Dengan penanganan yang lebih baik terhadap penyakit thalassemia ini, maka umur mereka banyak yang mencapai umur dewasa. Dua puluh tahun yang lalu umur mereka jarang yang mencapai 10 tahun, mereka umumnya meninggal oleh karena komplikasi penyakit Thalassemia seperti radang paru dan gagal jantung.

Seperti telah disebutkan di atas, di samping masalah medis terdapat masalah lain yang tidak kalah pentingnya bagi pasien-pasien thalassemia yaitu masalah psikososial. Dengan banyaknya pasien yang mencapai umur dewasa maka timbulah masalah, yakni bagaimana penanganan mereka yang telah dewasa, terutama dari segi mental dan psikososialnya. Mereka harus pergi sekolah dan mereka harus mendapatkan pekerjaan setelah sekolahnya selesai. Kemampuan serta keadaan fisik yang kurang sempurna memerlukan perhatian orang sekitarnya. Bagi mereka yang sudah 
dapat bekerja harus dicarikan lapangan kerja yang sesuai dengan kemampuannya.

Biaya penanganan seorang pasien thalassemia itu sangat tinggi, sebagai contoh biaya penanganan seorang penderita di negara Yunani pada tahun 1983 ialah 5000 dollar Amerika per tahun. Saat ini sudah pasti lebih tinggi lagi biaya tersebut. Dapat dibayangkan betapa besarnya beban biaya tersebut bila terdapat beberapa ratus kasus saja. Biaya tersebut sebenarnya dapat dipergunakan bagi keperluan lain seperti bagi pendidikan, seandainya jumlah kelahiran pasien thalassemia dapat ditekan. Atas dasar itu di negaranegara dengan frekuensi gen thalassemia tinggi seperti Italia, Yunani, Cyprus, Turki bahkan di Thailand, usaha menekan kelahiran pasien thalassemia berat ini sudah lama dilaksanakan. Di Cyprus umpamanya telah dapat menekan lebih dari 90\% kelahiran thalassemia berat dari yang diperkirakan. Usaha pencegahan ini umpamanya meliputi usaha yang retrospektif dan prospektif. Usaha retrospektif ialah usaha pemeriksaan yang dilakukan terhadap keluarga penderita yang sudah dikenal, sedangkan usaha prospektif ialah melakukan pemeriksaan skrining terhadap populasi yang belum dikenal. Strategi untuk pemeriksaan prospektif ini melalui tahap-tahap sebagai berikut:

1) Sosialisasi dan pendidikan kesehatan bagi masyarakat

2) Melakukan skrining mencari pembawa sifat dan pasangan resiko tinggi

3) Konseling

4) Diagnosis antenatal

Di Indonesia tahap-tahap itu sedang diusahakan oleh berbagai institusi, baik institusi penelitian maupun institusi pendidikan. Mudah-mudahan dengan usaha serta dukungan pemerintah, kelahiran kasus thalassemia berat yang saat ini terus meningkat, akan dapat ditekan. Sebagai ilustrasi pada saat ini terdapat lebih dari 1000 pasien yang berobat di Unit Thalassemia Bag. IKA FKUI/RSCM, meningkat 4 kali lipat dibandingkan dengan 20 tahun sebelumnya. Diharapkan pula bahwa bagi pasien yang telah ada, akan mendapat pelayanan yang lebih baik lagi. 